\title{
The Elite Teaching the Elite: Who Gets Hired by the Top Law Schools?
}

\author{
Eric J. Segall and Adam Feldman
}

\begin{abstract}
"[I]nstitutional prestige is at best a proxy for quality .... Nevertheless ... the relative ranking of a candidate's law school will be the single most important factor in predicting [academic] law job market success, beyond more direct measures of potential such as publications and teaching." ${ }^{1}$
\end{abstract}

Do you want to teach at a Top Ten-ranked law school? If so, you had better excel at something you will encounter years before you even consider applying to be a law professor. Something that has no relationship at all to the skills academics need. You better score extremely high on the Law School Admissions Test (LSAT) (or now at some schools the GRE). If you don't score toward the very top, you will likely not be admitted to a Top Ten-ranked law school. And if you don't attend a Top Ten-ranked law school, no matter what you accomplish during your time at the school you do attend (even one ranked among the top twenty) or afterward, your chances of teaching at a Top Ten-ranked law school are virtually nonexistent. The reality is that by far the most important credential one needs to teach at a Top Ten-ranked law school is to attend a Top Ten-ranked law school. The elite teaching the elite, who will then teach more elites.

Most prominent law schools publicly claim to strive for law faculty diversity. Both Harvard and Yale recently issued self-study reports, parts of which discussed faculty diversity. The Yale report said that "students were concerned not just with ethnic, racial, and gender diversity, but with methodological and political diversity." 2

Eric J. Segall is Kathy and Lawrence Ashe Professor of Law at Georgia State University College of Law. Adam Feldman is the creator of the Supreme Court Blog, Empirical SCOTUS, and recently completed postdoctoral work through Columbia Law School. Segall wants to make clear that he has spent twenty-six happy years at Georgia State and has never tried to change schools. Feldman received his law degree from a Top Ten law school-UC Berkeley School of Law (Boalt Hall). We mention this because this essay might be viewed by some critics as sour grapes. It most emphatically is not. We hope it is more like good red wine.

I. Tracey E. George \& Albert H. Yoon, The Labor Market for New Law Professors, in J. EMPIRICAL Legal Stud. I, I6 (2014).

2. John Forman, Jr. et al., Report of the Committee on Diversity and Inclusion 5 (Mar. I8, 20I6), https://law.yale.edu/system/files/documents/pdf/Deans_Office/diversity_ inclusion_report_3_23_20I6_to_community.pdf. 
Harvard's report said that "a diverse faculty is important not just so that students can see themselves in the people who teach, advise, and mentor them and be assured that there are faculty who understand their differences. It is also essential to advancing knowledge broadly and to pursuing ideals of justice in ways that recognize and include the experiences, aspirations, and needs of an even more diverse world."3 Other schools have issued similar reports. ${ }^{4}$

According to our examination of law school faculty, however, most schools are not meeting these goals. We examined law faculty profiles at the U.S. News 2019 top twenty-five law schools, as well as at a number of other schools across the country, looking at a variety of characteristics. ${ }^{5}$

Although it is not the focus of this essay, we did review the faculties' gender ratios and found that only thirty percent of those faculty members are women. (We also attempted to observe faculties' racial diversity but could not accurately code many faculty members' races based on their faculty profiles.) Much has been written, and more needs to be written, about the need for greater gender and racial diversity in law school hiring. But this essay emphasizes a different aspect of diversity, though this aspect also affects gender and racial diversity. ${ }^{6}$

We examined where law professors received their legal education. According to their websites, Harvard and Yale have 152 tenure-track or tenured faculty with law degrees from domestic institutions (some faculty have other advanced degrees or degrees from institutions outside the United States). All but three of those $5_{2} 2$ faculty members received their law degrees from U.S. News Top Ten-ranked law schools (and one of those faculty is a law librarian). This means that graduates of any of the other approximately rgo accredited American law schools outside the Top Ten have virtually no chance of being tenured professors at Harvard or Yale, regardless of their success in law school and/or post-degree achievements.

The numbers are not considerably different at other Top Ten-ranked schools. Stanford and Chicago combined have only seven tenure-track or tenured professors from outside the Top Ten schools (and four went to Northwestern, which was a Top Ten law school, according to the 2018 rankings), while Michigan and Pennsylvania have a total of six. All told, almost ninety-five percent

3. Bruce H. Mann et al., Report of the Task Force on Academic Community and Student EnGAGEMENT 6 (June 29, 20I7), https://hls.harvard.edu/content/uploads/2017/o7/TaskForce-on-Academic-Community-Student-Engagement-Report-Addendum.pdf.

4. See, e.g., University of Pennsylvania's Action Plan for Faculty Diversity \& Excellence (May 3I, 20I2),https://www.law.upenn.edu/cf/faculty/PennLawDiversityActionPlanFinal. pdf; University of Washington School of Law, Strategic Plan for Diversity, InClusion, EQUity AND Multiculturalism (last updated Oct. 20I7), https://www.law. uw.edu/media/ı40870/diversityplan.pdf.

5. U.S. News rankings have become the industry standard for comparing schools in most fields, including law. See, e.g., Mitchell Berger, Why the U.S. News and World Report Law School Rankings Are Both Useful and Important, 5I J. LEGAL EDUC. 487 (200I).

6. See, e.g., LaWanda Ward, Female Faculty in Male-Dominated Fields: Law, Medicine, and Engineering, I43 New Directions Higher Educ. 63 (2008). 
of the professors at the ten highest-ranked schools who received law degrees in the United States obtained their degree at one of those same schools. The following graph shows the relative percentages of professors at Top Ten-ranked schools and schools not ranked in the Top Ten who went to a Top Ten school:

\section{Breakdown of Whether Professors Went to Top Ten-Ranked Law Schools}

\section{Rank of School Where Professor Teaches}

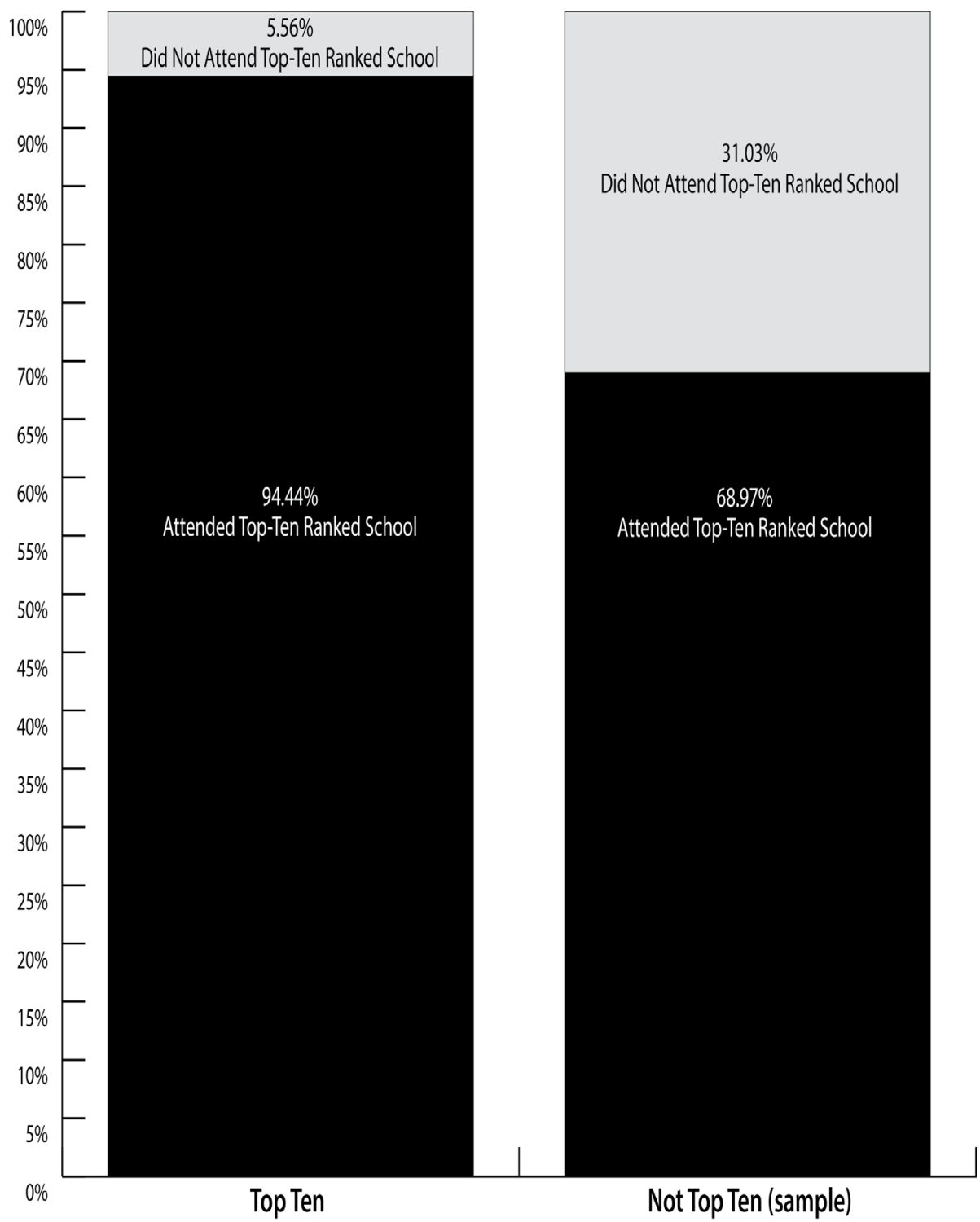


Focusing on absolute numbers, below is a breakdown of law schools attended by professors at Top Ten-ranked schools for all schools with two or more graduates.

Faculty at Top-Ten Schools by Schools Attended

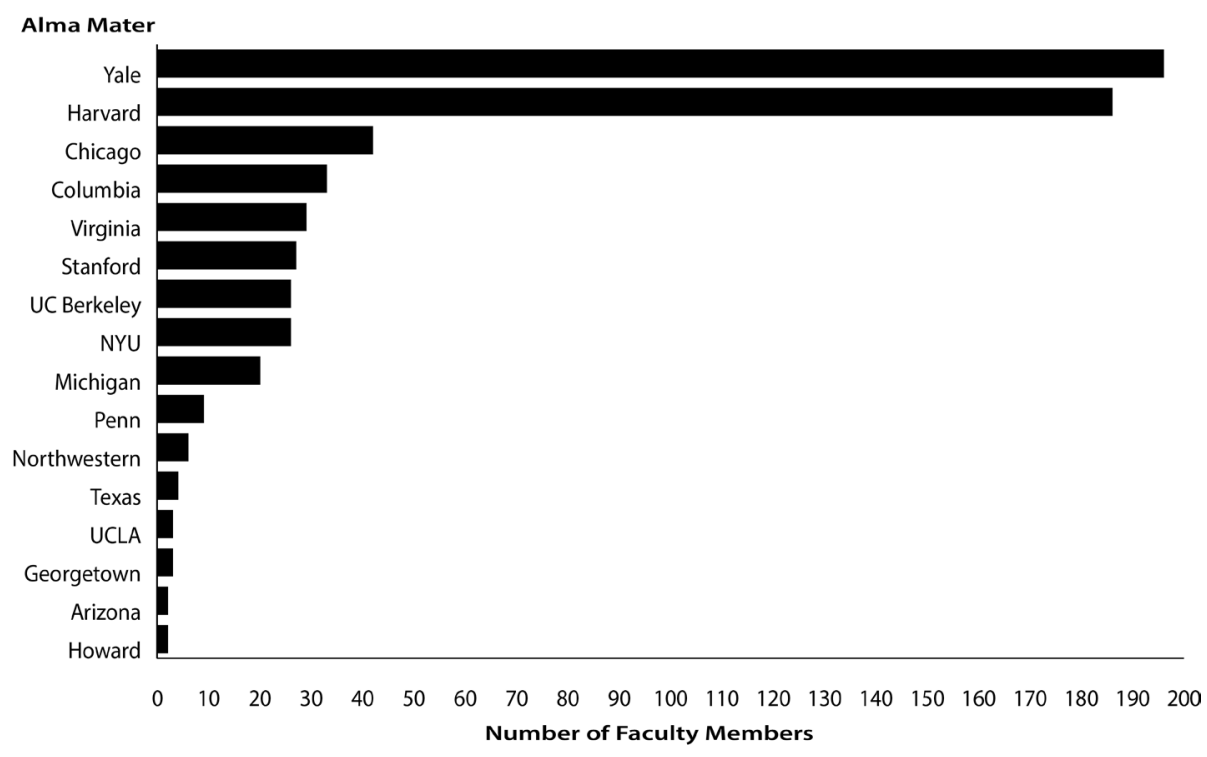

The following figure shows the percentage of law school faculty at each of the Top Ten-ranked schools who attended a Top Ten law school.

Faculty at Top-Ten Schools Who Attended a Top-Ten Law School

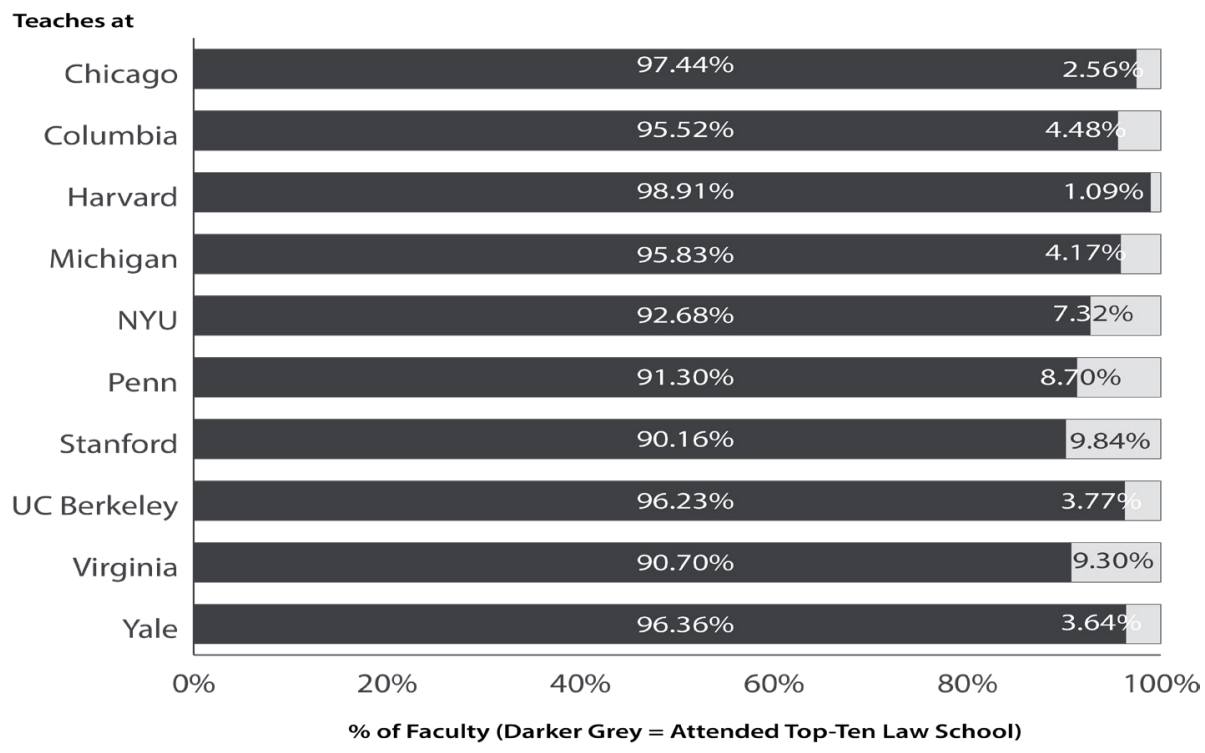


Faculty Who Teach at School Outside of the Top Ten and Attended a Top-Ten Law School

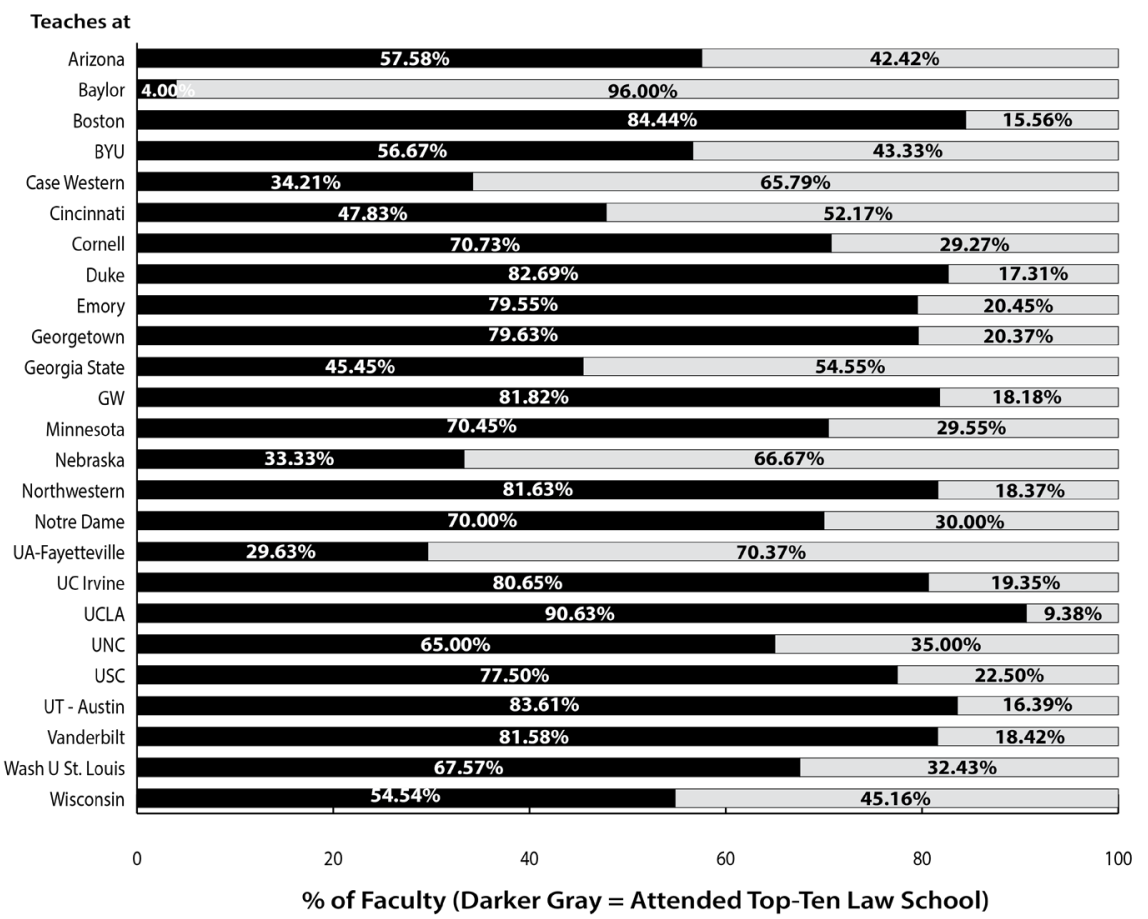

As the figure shows, almost ninety-five percent of the faculty members at each of the Top Ten schools who attended a U.S. law school attended a Top Ten law school. The percentage of professors who went to Top Ten law schools for the remainder of the top twenty-five schools is a bit lower, but even in those schools, more than eighty percent of the faculty attended a U.S. News-ranked Top Ten school. In other words, there is little diversity on the plane of law schools attended at our country's twenty-five top-ranked schools.

We also researched schools outside the Top Ten on a stratified random basis to select schools ranked thirty to forty, forty to fifty, fifty to sixty, sixty to seventy, and seventy to eighty. The following figure shows the percentage of faculty at the non-Top Ten law schools we examined who attended Top Ten law schools.

Among non-Top Ten schools there is still a strong bias toward hiring applicants who went to Top Ten law schools; but this bias-or at least a school's ability to hire applicants who attended Top Ten institutions-decreases as we move away from the Top Ten-ranked schools. When we isolate schools ranked between eleven and twenty-five, just under eighty percent of the faculties that attended U.S. law schools went to Top Ten-ranked schools. Looking at faculty from schools we sampled outside of the top twenty-five, only about forty-four percent of professors who attended a domestic law school went to a Top Ten school. 
Is it important that the twenty-five top-ranked schools hire eighty percent of their faculty from the Top Ten-ranked schools? We think it is. By limiting their hiring to the most elite schools (and just two, Harvard and Yale, account for more than fifty percent of all faculty in these schools with U.S. law degrees), these schools limit the range of pedagogical choices they adopt and provide for their students. There are many ways to teach law and set priorities for law students. The top-ranked schools do not have a monopoly on the best legal education methods. Moreover, for better or worse, how these schools teach future lawyers has a great impact on the other $6_{5}$ or so accredited law schools, but the law school experiences of their faculties are mostly limited to ten law schools. This inbreeding stunts creativity, experimentation, and growth, and might even prioritize the theoretical over the practical to the detriment of the legal profession. Moreover, since law schools do not teach law students how to teach, professors at Top Ten-ranked schools have only their shared experiences to rely on, which likely makes it difficult to improve how they teach their students.

One Yale Law professor told us she was not surprised that Yale turns out so many professors, as the Yale faculty focus on preparing their students to be academics. When we asked how they do that, she said by teaching them how to write good law review articles. We are skeptical that writing such articles should be the primary measurement by which law professors are judged. Moreover, there are data to suggest that "inbred" law professors, those whose first teaching jobs are at the same school from which they earned their J.D., have less scholarly impact than non-inbred professors. ${ }^{7}$ Given how often the Top Ten schools hire their own, these data suggest that, if the goal is to identify people who will become the most influential scholars, perhaps hiring entrylevel applicants from other schools would be a better tool to achieve that goal.

There are many reasons that nepotism is often strongly discouraged in both private and public employment. One of those reasons is fairness. Are the faculty at the top-ranked schools willing to argue that only graduates of those schools are the most qualified to teach at those schools? There are hundreds if not thousands of graduates of excellent law schools outside the Top Ten who have had distinguished legal careers. Yet they have virtually no chance of obtaining a tenured position at a Top Ten-ranked school. For example, as of the time of this writing, none of the 750 faculty members at the Top Ten schools attended Boston College, Cornell, or the University of Georgia, all ranked in the top thirty law schools by U.S. News.

Two Harvard professors suggested to us that one reason they hire so few non-Top Ten graduates is that hiring is quite time-consuming, Harvard can fill its needs through looking almost exclusively at graduates of the Top Ten schools, so there is little reason to extend the searches to other criteria. One must ask, however, whether the school would take the same position regarding other diversity factors. We seriously doubt it. The reality is that most high-

7. See Theodore Eisenberg \& Martin T. Wells, Inbreeding in Law School Hiring: Assessing the Performance of Faculty Hired from Within, 29 J. LEGAL STUD. 369 (2000). 
ranked schools do not see diversity in law school attended as an important diversity factor.

Justice O'Connor once explained why diversity in the student bodies of elite law schools is so important:

$[\mathrm{U}]$ niversities, and in particular, law schools, represent the training ground for a large number of our Nation's leaders .... Individuals with law degrees occupy roughly half the state governorships, more than half the seats in the United States Senate, and more than a third of the seats in the United States House of Representatives ... . The pattern is even more striking when it comes to highly selective law schools. A handful of these schools accounts for 25 of the Ioo United States Senators, 74 United States Courts of Appeals judges, and nearly 200 of the more than 6oo United States District Court judges. ${ }^{8}$

These future judges and political leaders are being taught by the graduates of only a handful of law schools-ten, to be precise. Our country and our government would be well-served by leaders with more diverse backgrounds. All nine Supreme Court Justices went to one of these ten schools (eight out of nine graduating from Harvard or Yale), and they were taught law almost exclusively by graduates of those ten law schools.

Finally, there may well be substantial discriminatory racial and class elements to the hiring practices of these schools. To attend an elite law school (a prerequisite to teaching at one), one must have extremely high college grades and LSAT scores. According to 2018 rankings, the median LSAT for Yale and Harvard admits was $173 .{ }^{9}$ The median GPA for admits to those schools was 3.93 and 3.86 , respectively. The Top Five schools all had median LSATs at I70 or above for admitted students. The lowest median LSAT for admits to a Top Ten school was I66, for UC Berkeley, and the lowest median GPA was 3.7, for Columbia.

The LSAT, at most, might predict first-year law school grades and perhaps bar exam performance. ${ }^{\text {Io }}$ But no one has ever suggested that there is any relationship between the LSAT and excellence as a law professor. Moreover, the LSAT is biased across both race and class lines. As to race, one study found that "[e]ven when diversity is a factor in admission decisions, the negative impact of the LSAT is so severe that among applicants with approximately the

8. Grutter v. Bollinger, 539 U.S. 306, 322 (2003) (emphasis added) (citations omitted).

9. U.S. Newes \&ै World Report 2018 Law School Rankings, https://www.usnews.com/best-graduateschools/top-law-schools/law-rankings (last visited Aug. I, 20I8). The U.S. News and World Report website lists the most recent version of their law school rankings and limits access to older iterations. The website currently hosts the 2019 edition which is slightly different from that in 20I8, which we used for this article.

Io. See, e.g., Katherine A. Austin, Catherine Martin Christopher \& Darby Dickerson, Will I Pass the Bar Exam: Predicting Student Success Using LSAT Scores and Law School Performance, 45 Hofstra L. Rev. 753 (20I7); David A. Thomas, Predicting Law School Academic Performance from LSAT Scores and Undergraduate Grade Point Averages: A Comprehensive Study, 35 ARIZ. ST. L.J. $\mathrm{IOO}_{7}$ (2003). 
same GPAs, whites consistently have the greatest chance of being accepted into ABA law schools."

The LSAT also results in a huge class bias. An article in The Atlantic put this sad but true statement in its title: "How the LSAT Destroys Socioeconomic Diversity." To do well on the LSAT, preparation classes are extremely important, and their average cost for in-person sessions is \$I300. According to this article:

While law schools are steadily becoming more racially and ethnically diverse, they remain overwhelmingly upper-middle class. Only 5 percent of students at elite law schools come from families that fall in the bottom half of the socioeconomic spectrum-a number that has hardly changed since the Ig6os. The Logic Games section [of the LSAT] contributes to this lack of socioeconomic diversity. If you can't afford to adequately prepare, it's a lot harder to earn the LSAT score you need to get into a Top I4 school. The vast majority-I80-of the 200 accredited U.S. law schools can't find jobs for 8 o percent of their graduates. That means that a low score on Logic Games might stop you from becoming a lawyer. ${ }^{12}$

Substitute the word law professor for "lawyer" and the LSAT plays an even larger role in eliminating many excellent prospective teachers from consideration based on their socioeconomic status. This point cannot be emphasized enough. A student from a top-ranked college with a 4.o GPA, but only an average-plus LSAT score, has almost no chance of gaining admission to a Top Ten law school. This is apparent from using the Law School Admission Council (LSAC) online calculator that shows the likelihood of admission to various schools based on a student's GPA and LSAT scores. ${ }^{\text {I3 }}$ Once they attend a non-Top Ten school, their chances of becoming a law professor at a Top Ten school are remote regardless of their post-education achievements. In effect, the LSAT, because it strongly affects the law school admission process, also strongly affects the law professor hiring process. The test was never meant for that purpose, and using it that way results in substantial class bias.

This class-based bias has not gone unnoticed by other scholars. As Professor Higdon found a few years ago:

the students who attend top-tier law schools are overwhelmingly representative of the elite socioeconomic class-often times as a result of merely being born to parents who were also a member of that class. As such, hiring faculty members

II. Aaron Salaymeh, Artificial Selection: LSAT Bias Affects Us All, HARv. L. REc. (Sept. 25, 2002).

12. Caroline Kitchener, How the LSAT Destroys Socioeconomic Diversity, THEaTlantic.com (Oct. I8, 2016), https://www.theatlantic.com/education/archive/2016/ı/the-lsat-is-rigged-againstthe-poor/504530/[https://perma.cc/AU 3 J-HUF9] (emphasis added).

I3. LSAC Official Guide to ABA-Approved Law Schools, UGPA/LSAT Search, https:// officialguide.lsac.org/Release/OfficialGuide_Default.aspx (last visited May ro, 2019). Several top twenty-five schools including Yale and Harvard do not participate in this calculation. The full list of non-participating schools can be viewed at https://officialguide. lsac.org/Release/UGPALSAT/UGPALSAT_OptOut.aspx. 
from primarily those ranks undermines a law school's ability to achieve socioeconomic diversity on its faculty and instead helps perpetuate a classbased monopoly within the legal academy to the detriment of all involved. ${ }^{14}$

Unless Top Ten-ranked schools are willing to say that only students who graduated from Top Ten school are easily the most qualified to teach at their schools, a doubtful proposition at best, the obsessive focus by elite schools on where law professor applicants received their degree should be seriously reexamined. Otherwise, these law schools will continue to comprise faculties drawn mostly from the elite classes resulting in an endless cycle of elite law professors handing down elite values to elite law students. The teaching of law should be better than that.

I4. Michael J. Higdon, A Place in the Academy: Law Faculty Hiring and Socioeconomic Bias, 87 ST. JoHN'S L.REV. I7I, I75 (20I3) (citation omitted). 